「報告」

\title{
手近な沉用機器を活用した映像配信による 板書型講義の簡便な遠隔講義実現とその実践
}

\author{
宮本 理人
}

徳島大学大学院 医歯薬学研究部 医薬品機能生化学分野

\begin{abstract}
要旨 — COVID-19，いわゆる新型コロナウイルス感染症の蔓延により本邦の教育機関においても積極的な感 染拡大防止策が求められることとなった。その一環として遠隔授業の活用が推奨され，充分な準備のないま ま多くの教員が急遽遠隔授業に取り組み始めている。板書は基本的かつ一般的な教育手法だが，板書型講義 の遠隔配信は容易ではない。筆者は板書の良さを活かした遠隔授業の方法を模索する中で，手書きで描く様 子を手許の汎用品カメラで取り込みながら講義を行う簡便な手法を開発した。本稿では特別な機器を要しな い, 板書型講義の遠隔化実現の一例としてこの手法を紹介するとともに，生化学系の講義で本手法を実践し た経験を共有化したい。
\end{abstract}

キーワード; 遠隔授業, オンライン授業, 板書, 講義配信, 新型コロナウイルス

\section{Suggestion of an easy and practical solution for translating chalk talks into remote lectures.}

\begin{abstract}
Licht Miyamoto
Department of Medical Pharmacology, Institute of Biomedical Sciences, Graduate School of Tokushima University

Abstract - A practical idea for giving remote lectures based on board writing without any special devices and my recent experience will be shared in the current manuscript. The rapid pandemic spread of COVID-19 has suddenly forced us to do remote teaching with little support. We need efforts and tricks to achieve chalk talks remotely compared with lectures with digital slides. I have tried a series of methods and successfully gave the lectures by capturing my handwriting with general cameras like smartphones at hand. It does not require quite high resolution and we can use relatively low-spec ones. Furthermore, it can be recorded and/or broadcasted on-line without assistance from other staff. Here, I would like to share and discuss my experience of giving the remote lecture on the biochemistry course dealing with molecular metabolism and cellular signaling in the faculty of pharmacy, including feedbacks from my students.
\end{abstract}

Keywords; remote lecture, chalkboard writing, chalk talk, internet, COVID-19

*) Correspondence: Department of Medical Pharmacology, Institute of Biomedical Sciences, Graduate School of Tokushima University, Tokushima 770-8505, Japan

E-mail: licht_corresp2011[at]yahoo.co.jp

**) 連絡先 : 770-8505 徳島市庄町 1-78-1 徳島大学大学院 医歯薬学研究部 医薬品機能生化学分野 


\section{1. はじめに}

2019 年 11 月から 12 月にかけて中国, 武漢市周 辺に端を発した COVID-19, いわゆる, 新型コロ ナウイルス(SARS-CoV-2)感染症はまたたくまに 世界中に広がり，世界保健機関(WHO)の声明 ${ }^{1)}$, を待つまでもなくパンデミックの様相を呈した。 当然，教育現場への影響も大きく，本邦において も年度明けまでの小学校, 中学校, 高等学校, 特 別支援学校に対寸る臨時休校要請 2), に続き, 大 学等の高等教育機関においても授業開始にあたっ て遠隔授業の活用を含む対策が求められることと なった ${ }^{3)}$ 。当初, 授業開始を遅らせることで通常 通りの講義を行うとした大学等も少なくなかった が, 2020 年 4 月 7 日の新型インフルエンザ等対策 特別措置法に基づく緊急事態宣言発出, 同 16 日 の対象地域全国拡大に伴い, 講義開始時期の見通 しが立たなくなったこともあり，4月 24 日の調査 では 99\%の大学等が遠隔講義の導入を決定もしく は検討している4)(図 1)。公共交通機関に恵まれ， 比較的狭い国土に多くの大学等を有することや制 度上の問題などから, 我が国の遠隔授業への対応 は遅れているとされていたが, 大多数の教職員に とっては, 殆ど準備のないまま急遽遠隔授業の導 入が求められることとなったといえる。

高等教育の現場に限って言えば，学会などで の口頭発表がほぼ完全にデジタルスライド化され た近年, デジタルスライドのみを用い全く板書を 行わない講義スタイルも増えているが, 講義や授 業が行われる殆どの教室に遍く黒板やホワイトボ 一ドが設置されているように, 板書は最も一般的, 基本的な教授法として根付いている。ここでは踏 み込むことを避けるが，それぞれの改善に向けた 取り組みが多数議論されており, 一長一短を認識 し，講義内容の特性に合わせた工夫を伴う活用が 求められている。

筆者が担当する生化学系の講義では主に物質 代謝を扱い, 化合物の構造変化を理解させること が重要であることから, 板書を活用し, 話題の中 心を明確にした講義が有効と考えている。遠隔授 業への対応にあたって, 講義室の黒板やホワイト
ボードを用いたり，デジタルホワイトボードによ る配信などを事前に試したが，特に解像度を中心 に満足いく結果が得られなかった。様々な検討を

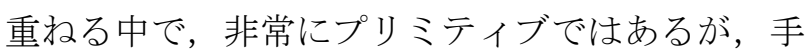
許で紙に書きながら講義をする様子を手近な汎用 機器で撮影もしくは生配信する方法が板書型講義 の遠隔授業化の手法の一つとして有効と思われた。

地域によっては教職員の出勤もままならぬ 中，有志によって web 上を中心に，様々な配信プ ラットフォームの使い方や比較, 実践経験など, 遠隔授業を始めるにあたって参考となる様々な情 報の共有化が急速に進められており，多くの先生 方がそれらの情報を元に遠隔授業の準備，もしく は実践を始めていると思われる。web 検索状況を 調べると 2020 年 3 月最終週から「オンライン授 業」や「遠隔授業」に対する検索頻度が飛躍的に 上昇しており，教員による情報収集のみならず， 社会の関心も高まっていることがうかがわれる (図 2)。しかしながら, 板書型講義の遠隔配信化 に関しては未だ情報が少なく，その実践に戸惑っ ている様子が web 上でも散見される。

そこで，筆者の行っている板書型講義の簡易 な遠隔配信化について，手法ならびにその実践に 対するフィードバックを公開, 共有化し，その効 果を検証するとともに，喫緊の必要に迫られてい る先生方に板書型講義の遠隔配信化解決策のヒン トの一つとして頂くことを目的に本稿を執筆した。

\section{2. 調查方法}

\subsection{Web 検索にみる遠隔授業への関心度合い}

遠隔授業への関心度合いの経時的変化を「オン ライン授業」と「遠隔授業」の二つを検索クエリ 一とし, google 社の 2018 年 4 月から 2020 年 4 月 までの web 検索頻度情報を取得してグラフ化した。

（図 2）総検索数は非公開であり, 縦軸は相対值 (arbitrary unit)で示した。

\section{2 遠隔講義の実践とアンケート調査の実施}

講義の実践は徳島大学薬学部における生 物化学 3 (履修登録者; 学部 2 年生 86 名, 代謝生 
化学, 細胞情報学の基礎を中心とする必修科目) を対象に行った。イントロダクションを含む 90 分 間の講義を 5 回行い, 視聴状況と理解度の確認を 兼ねたアンケート調査を実施した (全履修登録者 に対する有効回答率 96.5\%)。講義の配信には webex (Cisco Systems, Inc., San Jose, CA)および youtube (San Bruno, CA)のシステムを利用した。一 部の質問に関して 10 段階の numerical rating scale を用い, 半定量的解析を行った。調查内容は本学 における倫理審查の対象外であるが，アンケート 調査の実施にあたり, データの匿名化解析, イン フォームドコンセントの実施等, 研究倫理上適切 に取り扱った。

\section{3 アンケートの調査項目}

用いたアンケートの調查項目は以下の通り。 ほか, 自由記載欄により理由についても調査した。 図 7

手書きの板書は概ね充分な解像度, 大きさで 見えていますか?

音声は概ね理解できる程度に聞こえていま すか?

図 8

通常の対面形式での講義はまだ実施できて いませんが, 通常の講義と本形式による遠隔配信 ではどちらが好ましいと思いますか? (10 段階)

今後通常の対面形式での講義が可能となっ た場合, 対面形式一変更するのと本形式を継続す るのではどちらが好ましいと思いますか?

図 9

多くの先生方はスライド形式での遠隔講義 を行っていると思いますが, 本形式と比べてどち らの方が好ましいですか? (10 段階)

黒板またはホワイトボードを用いて通常の ように板書を行った講義を収録配信した場合と 本形式を比べてどちらが好ましいと思います か?

\section{3. 汎用機器を用いた板書型講義の簡便な遠隔配 信化}

筆者が採用した方法は, 板書と同様, A4 サ
イズの白紙に手書きで書き込みながら講義を行い， それをタブレット端末等のカメラで取り込むこと によりデジタル化を行う。(図 3,4) 手許で撮影し ているため, スマートフォンや安価なタブレット 端末等の手近な汎用品のカメラでも充分なスピー ドと解像度が得られる点がメリットとして大きい。 配信プラットフォームやソフトウエアも Cisco webex, Microsoft teams, Zoom, Youtube 等, 多<の システムが利用可能である。筆者は純正カバーを スタンドとしてipadにより撮影した映像と音声を 用い， webex によるリアルタイム配信および， youtube による録画配信で遠隔講義を行っている。

（図 3,4）同様に各種スマートフォン等のカメラ も利用可能であり, 固定に用いるスタンド代用品 の入手も比較的容易である。リアルタイム配信は 不可能だが，録画配信を行うならデジタルカメラ 等で動画撮影したものを改めてパソコンから配信 するのが簡単である。（図 5）100 円ショップ等で 小型の三脚が入手でき, 自由な角度で固定しやす い。比較的画素数の少ない古い，もしくは安価な 機種でも画質的には充分だが，バッテリー容量の 大きいものか， $\mathrm{AC}$ アダプタ等の外部電源が利用 可能な機種がふさわしい。筆者の手許の機器では バッテリー容量が小さいため, 連続動画撮影が 15 分程度しかできず，長時間の講義の収録には不向 きであった。また, 静止画撮影と違い, 動画撮影 時には記録に用いるメモリーの転送速度にも注意 が必要である。

使用する機器にもよるが, 図 3,5 の上段の 写真に示寸ように, A4 サイズの大部分が撮影視野 に入るようにカメラの固定が可能であるが，下段 のようにカメラをより下に向け，やや手前に紙を 設置した方が映像に歪みが少なく，より大きく見 えるため伝わりやすいであろう。（図 4）音声に 関しては，可能であればヘッドセット等のマイク を利用するとより明瞭だが，筆者の経験では ipad の本体内蔵マイクでも概ね問題なく音声が伝わっ ているようである(図 7)。

筆者の生化学系の講義では 90 分の講義に 対して, A4 用紙 4〜5 枚程度の板書を行っており, 動画の乱れなどの可能性を考え, 参考資料として 
ハンドアウトをスキャナで読み取ったものを講義 後に manaba (株式会社 朝日ネット, 東京) のシス テムを利用して受講者へ提供している。

\section{4. アンケート調査とその結果}

本形式での遠隔配信の効果を検証するに あたり，まず，学生の視聴環境を調査した。(図 6)

本学では 2019 年度より BYOD (bring your own device)が実施され，ノートパソコンが必携化 されたこともあり, 8 割弱の学生がノートパソコ ンを視聴ツールとしていた一方で, 1 割強の学生 は小型のスマートフォンを用いていた。(図6) 板 書型講義の受講にあたっては画面の大きさが一つ の鍵となるが，別途提供している講義ハンドアウ トによりそれを補い，使い慣れたスマートフォン で視聴するという受講スタイルがうかがわれた。

当初, 学生がスマートフォン等にて多くの オンライン講義を受講することにより, 通信費負 担の増大を招くのではないかという議論が多くな されていたが, 大学構内を含め, 殆どの学生が wifi による受講環境を何らかの方法で確保していた。

(図 6) 多くの学生は通信量の削減よりも画像の 安定化, 高画質化を求めており, それはアンケー トの自由記載欄からもうかがえた。やや音が小さ いとの指摘もあったが, 筆者による ipad を用いた 配信では音質, 画質いずれも受講に充分な品質が 概ね保たれていた(図 7)。

本年度の講義ではまだ対面講義を実施で きていないが, 通常の対面講義と本形式とでどち らが好ましいかを調査したところ, 本形式がより 好ましいとする意見が半数をやや超えた。(図 8 左) 外出せずに受講できる, 感染リスクを抑えられる などの遠隔授業に伴う利点のほか, 板書が見やす く集中できることを挙げる意見などが理由として 多く寄せられた。一方, 周囲に友人がいることや 質問しやすいことを理由に対面講義を支持する意 見も多かった。今後, 対面講義の実施が可能にな った際にじうすべきか, という質問にも同様の傾 向が見られ, 半数をやや超える学生が本形式での 遠隔講義の継続を希望する一方で対面講義への変 更を希望する学生も半数近くに上った。(図 8 右)
さらに，他の遠隔講義方式との比較意見を 調査した。最も多く行われているであろうデジタ ルスライドを用いた遠隔講義と, 手書きによる本 形式のどちらが好ましいかについて訊ねたところ， デジタルスライドを非常に好む学生が一定数見ら れるものの，本形式の方にやや多く支持が集まっ た。(図 9 左) スライドの利点としては, 構造式 が綺麗, 見やすい, 図が綺麗, といった見た目の 良さを挙げる学生が殆どであった。一方, 本形式 では，流れが理解しやすい，先生の考え方がわか る，考えながら話を聞ける，集中しやすい，など が利点として挙げられ，本形式を採用するにあた って意図した目的が概ね達成されているように感 じた。もちろん, 両方式は併用可能であり, 本稿 で紹介したような簡素な設備しか無かったとして も，まとめの図などを別途作成し，メールなどで 配布したり，カメラで映すなどの対応が可能であ り，手書きのみに拘らず，必要に応じて柔軟に対 応するとより教育効果が高まると思われる。

さらに, 板書型講義の遠隔配信として多く 見られる，講義室での収録配信との比較意見を調 查したところ，教員の様子が見えるというメリッ トよりも，板書自体がはっきり見える本形式を好 ましいと感じる学生が多かった。(図 9 右) 通常の 対面講義時でも前の学生の頭や文字の大きさ等の 問題で板書の見えづらさを不満と感じる学生が一 定数おり, 図らずしも本形式が解決方法の一つと なったようである。

\section{5. 考察と総括}

板書型講義を遠隔配信する場合，1) MAXHUB (株式会社 KIC, 東京)などのハイブリッ ド型電子ホワイトボードを用いる。2) Good Notes, google jamboard などのデジタルホワイトボード アプリを利用する。3) リアルタイムでの板書を諦 め, デジタルスライドもしくは事前に手書きの資 料を作成する。4) 講義室で実際に板書したものを 撮影, 配信する。などの対応が一般的に考えられ る。

電子ホワイトボードを所有していれば1) の手法がエレガントだが，導入済みの教室数が充 
分とは思えず，また，構内への立ち入りが制限さ れている場合は利用ができない。そこで多くの場 合, 2) 4) の対応が考えられるであろう。板書型講 義のデジタル化として思いつきやすいのは2)と思 われるが，実用的にはペンタブレットやアップル ペンシルなどの手書き入力デバイスが必要な上, 板書と同等の描画クオリティーを保つのは容易で はない。筆者が配信に用いている webex にはホワ イトボード共有化の機能が実装されており, 事前 に利用を試みたが, 解像度の問題に加え, タブレ ット上に思い通りに描くのは予想以上に難しく, 板書代わりとして講義に供するには相当量の練習 が必要と感じた。

手書き資料を事前に配信する方法では通信 量が非常に少なくてすむ利点がある一方, 板書型 講義の様々な利点が失われてしまう。講義室での 板書型講義を配信する際は広い黒板全体を写すと かなり高精細の撮影機材でないと板書内容がはっ きり理解できず，まさに板書している部分を中心 にして配信しようとすれば慣れた撮影者が必要と なる。板書型講義の遠隔配信化に関する既報の多 くは映像機器の高画質化や撮影手法の改善により 講義室からの配信にかかる問題を解決しようとす るものであった。(5-7)など） しかしながら, アン ケート調査の結果からも, 実際に対面講義をする のでなければ講義室の設備をわざわざ利用する必 要性は低いと考えられる。(図 9 右)

これらの方法と比べ, 本手法は動画撮影が可 能な手近な汎用機器さえあれば特別な準備無く, しかも教員一人で容易に板書型講義の遠隔配信を 実践できる点で優れている。急な遠隔講義への対 応を求められている現在, 同じような手法に辿り 着き, すでに実践を始めている先生もいるかもし れないが，調べた限り，本手法と類似の方法を紹 介する学術的先行文献は皆無であった。

通常の対面講義と比べ, 本形式では教員の 顔や身振り手振りといった非言語的情報が伝わら ないという問題点が挙げられる。このような問題 はスライドを用いた遠隔配信においても同様であ るが, 配信プラットフォームの機能等を上手に活 用し，質疑応答などの双方向コミュニケーション
を講義に交えることで改善できると考えられる。 また，長時間の動画配信に伴う通信量増大の問題 においても, 教員一人で操作可能な利点を活かし, 学生の視聴環境に応じて, 不要な場面ではカメラ を切ったり静止画に切り替える等の対応が可能で ある。

現時点でのもう一つの課題として, 実際の 教育効果が従来の対面講義と比較してどうであっ たかが不明であることが挙げられる。グループ分 け等による充分にコントロールされた比較研究自 体が困難なことに加え, 昨年度との比較検証にも 試験の実施までまだかなり時間を要するため, 教 育効果の比較に関しては今後別の機会を用いて行 うことにしたい。

コロンブスの卵のようなプリミティブな 手法であるが，喫緊の問題としてお困りの先生方 に，特別な機材を要せず簡便かつスムーズに板書 型講義の遠隔配信を行う実用的なアイデアの一つ として頂くべく本稿にて報告した。本手法ならび にそのフィードバック情報を参考に，それぞれの 状況に応じて改善, 改良しながら活用して頂けれ ば幸いである。

\section{謝辞}

遠隔講義に関するノウハウを共有して頂くととも にご助言頂いた, 本学医薬品機能生化学分野教授, 土屋浩一郎先生, ならびに, 医薬品情報学分野准 教授, 佐藤陽一先生に感謝申し上げます。不慣れ な遠隔講義に対する本学薬学部の学生諸君の積極 的な参加とフィードバックにも感謝致します。

\section{筆者の COI 情報開示}

本稿に関する申告すべき COI は無い。

\section{参考文献}

1) 世界保健機関: WHO Director-General's opening remarks at the media briefing on COVID-19, 2020 年 3 月 11 日, 2020

2) 首相官邸: 内閣総理大臣緊急記者会見, 2020 年 2 月 29 日, 2020 
3) 文部科学省: 文部科学省高等教育局長通知, 2020 年 3 月 24 日, 2020

4) 文部科学省: 新型コロナウイルス感染症対策 に関する大学等の対応状況について, 2020年 4 月 24 日, 2020

5) 坂本良太ら:「高精細低容量な板書講義映像生 成システム」, 日本教育工学会論文誌 33, 4149, 2019

6)錦織修一郎ら:「黒板講義を対象とした遠隔講 義のための講義自動撮影システムの構築」, コ ンピュータと教育 57,63-70,2000

7）渡辺健次ら:「高精細映像を用いた板書型遠隔 講義のための黒板画像遠隔提示システムの実 現」, 教育システム情報学会誌 19, 218-223, 2002

\section{図表}

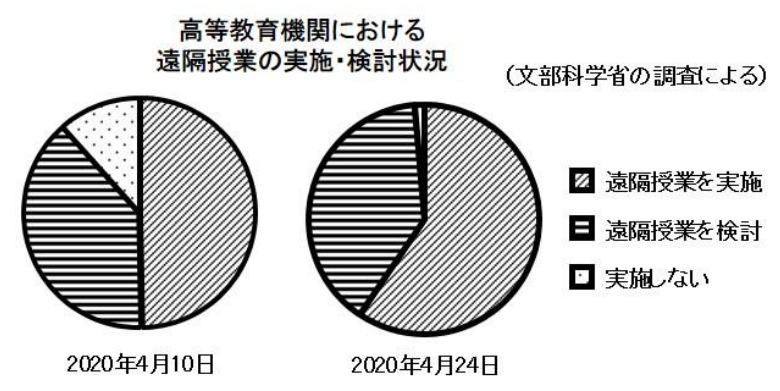

図 1．高等教育機関における遠隔授業の実 施・検討状況（文部科学省の調査による） web検索頻度にみる遠隔授羙への関心度合い

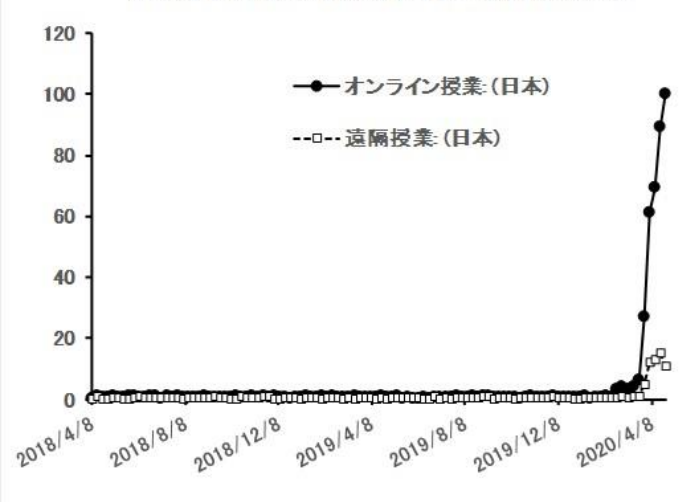

図 2. Web 検索頻度にみる遠隔授業への関心 度合い
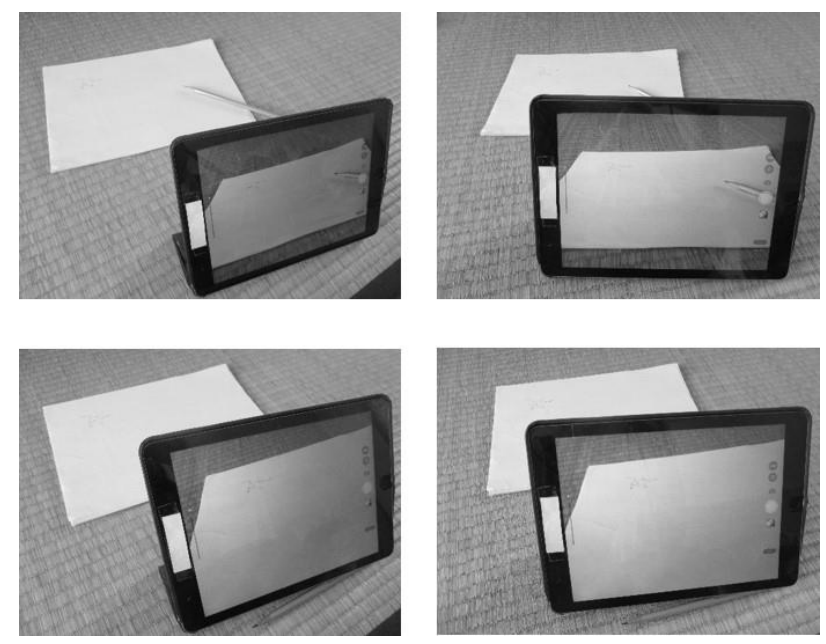

図 3.Ipad を用いた映像配信の設置例
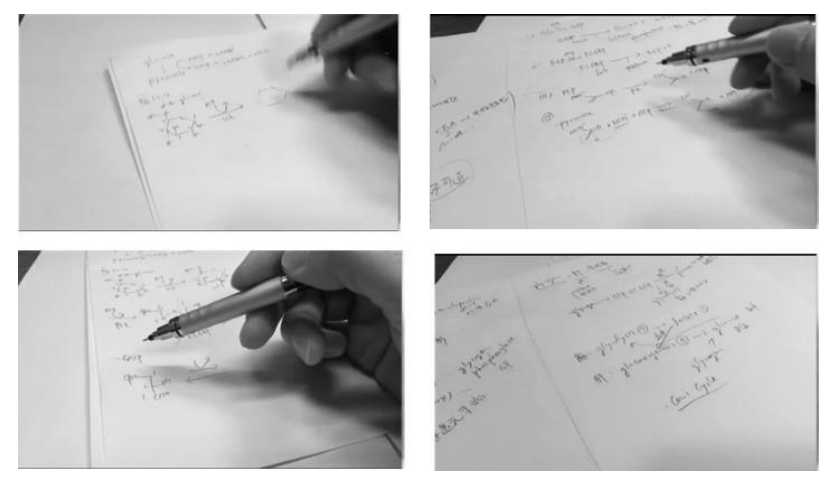

図 4.Ipadによる実際の講義配信 (受講画 
像)の例
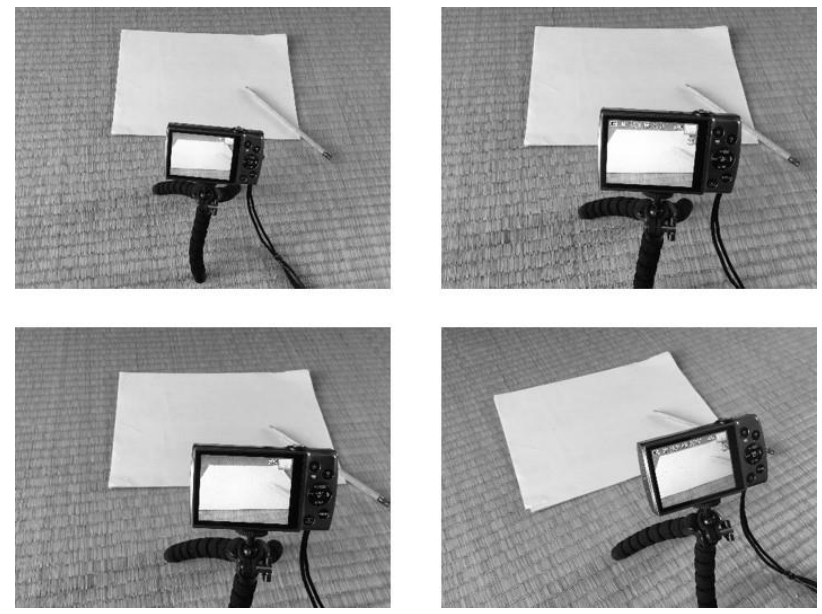

図 5. デジタルカメラを用いた映像配信の 設置例

\section{学生の視聴環境}

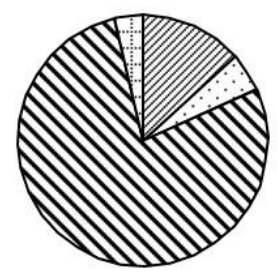

囚 スマートフォン (<6 inch)

口 タブレッ端末 (>7 inch)

\ ノードソン

回 デスクッッパソコン

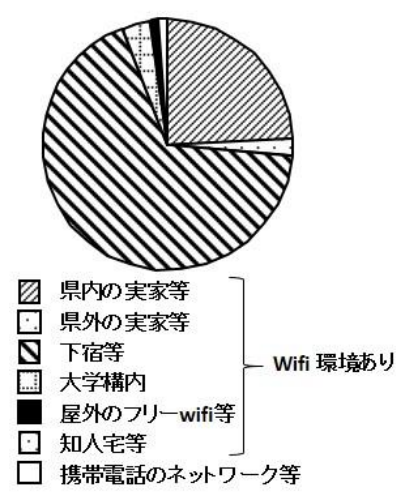

図 6. 受講者の視聴環境

\section{視聴品質の調査}

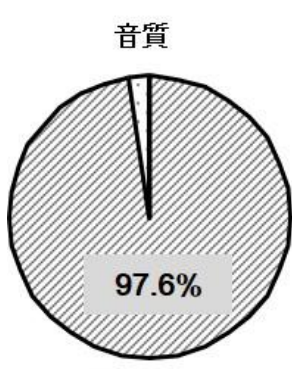

句は

Gいい

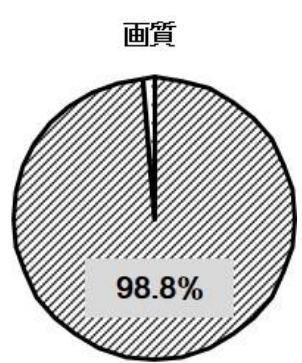

田心
図 7. 視聴品質（音質, 画質）の調査

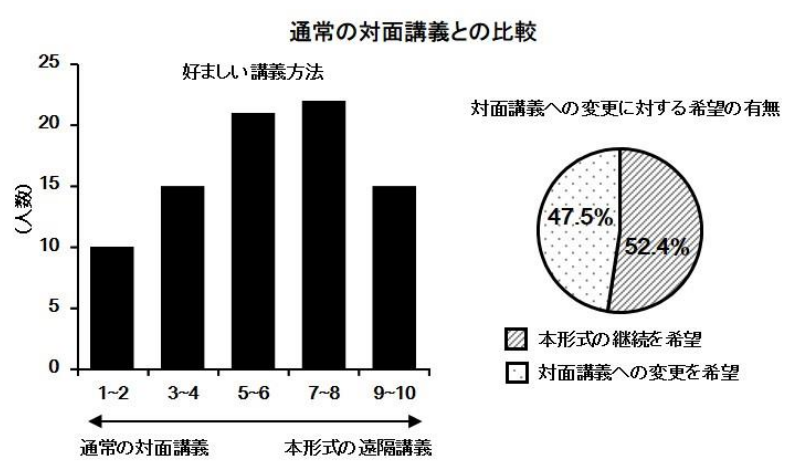

図 8. 対面講義との比較調査

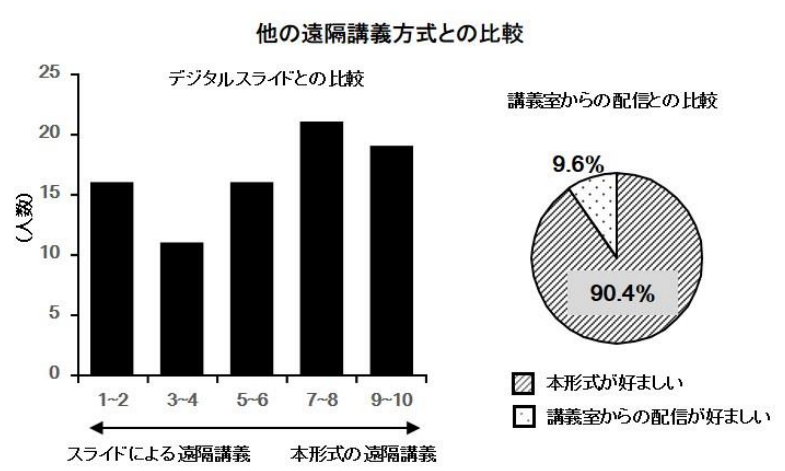

図 9. 他の遠隔講義配信方式との比較調査 